\title{
Culture as a Problem in the Translation of Jordanian Proverbs into English
}

\author{
Bakri Hussein Suleiman Al-Azzam*
}

Department of English Language and Literature and Cultural Studies, Faculty of Arts-The Hashemite University, Jordan

Corresponding Author: Bakri Hussein Suleiman Al-Azzam, E-mail: bakriazzam2013@gmail.com

\section{ARTICLE INFO}

\section{Article history}

Received: August 18, 2017

Accepted: October 01, 2017

Published: January 05, 2018

Volume: 7 Issue: 1

Advance access: December 2017

Conflicts of interest: Non

Funding: None

\begin{abstract}
The study aims at identifying the cultural problems, encountered in the translation of Jordanian proverbs into English. The significance of the study stems from the fact that it stresses on the social, colloquial, and folkloric use of proverbs that adds to the various implications of them. It relies on the selection of proverbs that are used and understood in different regions of Jordan. They address different social and cultural issues, and this makes indispensible the relationship between Jordanians and their cultural and social values. The conventions of the proverbs reflect their historical background, and the actual incidents or events that have led to their formation, utterance, currency, and frequency. The whole proverbial context has been pivotally and elementally noticed in proverbs' construction, and this fact enhances both the utterer and the audience in the comprehension of the proverb. Translating the selected proverbs into English collides with many challenges, of which the cultural ones are observed as the most manifest. What adds to the translation challenges is the colloquialism of the proverbs, which gives them enough semantic, social, and cultural values that cannot be stripped or ignored in the literal translation of the proverbs.
\end{abstract}

Key words: Translation, Proverbs, Jordan, Culture

\section{INTRODUCTION}

Pareminology is the study of proverbs, and it is concerned with how such a short phrase or sentence provides an advice or reflects a truth formed by the long experience of social groups. Meider (2004:4) defines the proverb as "a short, generally known sentence or folk which contains wisdom, truth, morals, and traditional views in a morphological and memorizable form and which is handed down from generation to generation". Proverbs convey messages indirectly and often fi uratively; the meaning they entail are socially understood as people share the same experience and inherit the exact aspects of proverbs. Norrick (1985:78) portrays the same idea in defining proverbs as "traditional, conversational, didactic genre with general meaning, a potential free conversational turn, preferably with fi urative meaning".

Proverbs occupy a significant element in people's social life. They are semantically pithy, and holding metaphor, and direct and indirect informative content. People express their long experience through resort to proverbs, as such a linguistic phenomenon is used to express newly arising situations. Though proverbs are normally short, they can convey themes of long conversations, in an expressive manner. Indeed, they are linked with social events and stories, from which lessons can be taken and applied on similar occasions.

Proverbs are common to almost all communities. Yet, each culture enjoys its own repertoire of proverbs which can be viewed as highly informative sources about the traditions and popular beliefs of a community of people. Characterized by both universality and diversity, proverbs and maxims have been used by a great number of people in different parts of the world and at different periods in time as they are deeply rooted in a wide variety of cultures worldwide, in addition to their ability of highlighting the specificity of each particular culture. What a proverb is exactly or rather what constitutes a proverb has puzzled the scholars and critics of all ages and there is a great variety of opinions relating to its definition. Some linguists go as far as to say that "there is no generally accepted definition which covers all specifics of the proverbial genre" (Grzybek, 1994:227). Yet, the defin tion offered by W. Mieder (2004:4) is quite comprehensive stating that "proverbs are short, generally known sentences of the folk that contain wisdom, truths, morals, and traditional views in a metaphorical, fixed, and memorizable form and that are handed down from generation to generation".

In the Arabic culture, as is the case might be so in many other cultures, the sizable body of proverbs and maxims survived in time because of the key role they played in rhetoric and oratory. Besides, they are rooted in folklore and related to other forms of folk literature, such as riddles and fables, the origin of which is in oral tradition. Some linguists, as stated by Muntean (1969:37), even consider proverbs as deriving from different genres of folk literature, such as stories, jokes, songs, nursery rhymes, fairy tales, and anecdotes which contain certain set phrases and expressions very 
similar to proverbs becoming in time independent from the literary work. Yet, they are considered simple poetic forms, presenting such fundamental prosodic features as rhyme, alliteration, rhythm, etc.

According to Piirainen (2007:208), most researchers nowadays consider that the study of modern phraseology is unthinkable without taking into account cultural aspects of language. The cultural foundation of phraseology is now seen as having as important a role as aspects concerning its semantics and syntax, since phraseological units tend to absorb and accumulate cultural elements. The interconnectedness of culture and phraseology becomes evident especially when trying to establish the motivating links between the literal and the fi urative meaning of a phraseological unit (ibid. 208, 217).

Initially, proverbs were conceived as authoritative words, having the role of guiding people's behavior, tracing the guidelines for their moral, religious, philosophic, legal behavior, being the first unwritten set of laws of humanity. They were used to pass judgment, give advice, criticize or praise others etc., rather than to express universal truths.

Moreover, many proverbs coincide in their message in different cultures, reflecting the same kernel of wisdom. Some coincide only in their essence, but are expressed in different formal "coating", particular to each culture, and some, even coincide in their form. Gyula Paczolay (cited in Paul Hernadi and Francis Steen, 1999: 14), in his study on proverbs, found 106 proverbs that occurred in at least 28 of his 55 surveyed European languages and sometimes, even had additional equivalents in non-European tongues, such as Arabic, Persian, Sanskrit, Chinese or Japanese. This, according to Cezar Tabarcea, (1982:23) could be a consequence of three phenomena. First, most proverbs are the expression of similar experiences of life-in certain situations, regardless of the period of time or the cultural and geographical space they live in; people reveal the same kind of emotions: the same joy, sorrow, anxiety, etc.; many activities are common to all communities; there are universal phenomena, such as birth, death, weather conditions, seasons, etc. which are reflected in each culture, and hence, in its proverbs. Second, many proverbs had a common origin like the ones derived from the Bible or ancient writers. Third, proverbs often "migrated" across linguistic borders or through many centuries, being borrowed from different languages and cultures.

Like idioms, proverbs "are special, fixed, unchanged phrases which have special, fixed, unchanged meanings" (Ghazala, 1995:142). Proverbs, however, are different from idioms in the sense that they display shared cultural wisdom. In other words, proverbs are easily understandable and, in most cases, the speaker may utter only the first part of the proverb to express the whole meaning. Thus, "do not count your chickens" is used instead of "do not count your chickens before they are hatched". Although proverbs are considered as culture-specific because they are very bound to culture, many proverbs have direct equivalents in different languages. For instance, the English expression "out of sight, out of mind" has a similar proverb in Arabic غايب عن العين, غايب عن الذهن.
Phraseological expressions like proverbs and idioms always cause a lot of problems not only to translators but also to foreign language learners. Foreign learners usually find difficulties in recognizing an expression as proverbial/idiomatic or not, and then grasping its exact meaning. This is mainly due to the fact that such phraseological expressions may embody a metaphorical sense that makes the comprehension of these linguistic units difficult if not sometimes impossible. For example, the meaning of an idiom cannot be deduced from the meaning of its individual words. In addition, both the source and the target cultures have a great impact on the comprehensibility as well as the translatability of such fixed expressions

Proverbs may have similar occasions and similar connotations in different cultures, but there may be a mismatch in the way they are conceived. Translators should not always rely on the borrowing or imitation of proverbs. Al-Budayri (2015:4) says "in spite of the universal features that may be reflected in proverbs, some misconceptions and misunderstanding may occur in translation because of the difference in the audience recognition of proverbs' connotations and implications. He (ibid) adds "translators should not depend on borrowing or imitation when they deal with proverbs, ...... and since cultural values are elemental in regional proverbs, and can form cultural values of them, enough explanation is necessary to bridge the gap between the source language and the target language".

Arabs are featured as motivating and motivated in their speech and by their wording, due to the stimulating power of Arabic. Hitti (1958:90) puts it "No people in the world, perhaps, manifest such enthusiastic admiration for literary expression and are so moved by the word, spoken or written, as the Arabs. Hardly any language seems capable of exercising over the minds of its users such irresistible infl ence as Arabic". This paper conducts a number of proverbs used by Jordanians, and points out the situations in which they are expressed. Besides, it investigates some challenges arising in the translation of these proverbs into English. Although translating proverbs has received enough attention from linguists and translation scholars, there are still some proverbial linguistic and cultural aspects to be investigated. What adds to the complications of translating these proverbs is their social, cultural, and linguistic references that cannot be similarly felt in the target language. Differently put, the study addresses the cultural problems of translating proverbs taken from Jordanian colloquial Arabic into English.

\section{STATEMENT AND PURPOSE}

Everyone understands the importance that proverbs have in every language. In the form of short, easily memorable phrases, proverbs contain a great treasure of folk wisdom, and through use of a short proverb, it's often easier to express an idea better and more convincingly, than with a long speech. Translation in general is difficult; yet the translation of proverbs can be more problematic.

Taking into consideration the great importance of phraseological units like proverbial and idiomatic expressions, and believing in the difficulties that may be posed while 
translating this type of fi urative language, this article primarily seeks to examine the types of difficulty encountered by translators while rendering culturally bound proverbs, and tries to suggest solutions and identify strategies that may help to limit or avoid these difficulties. More specificall, it aims at investigating challenges arising in the translation of Jordanian colloquial proverbs into English. It further attempts to examine the type of difficulties encountered while translating Arabic proverbs within a Jordanian context, suggest solutions and identify strategies that help to limit or avoid the arrived at difficulties

\section{THE CULTURAL SPECIFICITY OF PHRASEOLOGY}

Although language plays a central role in the communicative process, communication seems impossible if the speaker and the hearer do not share some basic knowledge and have at least a common referential framework. As put by Nida (1999:2-7), language and culture are thus viewed as two similar interdependent systems, i.e., they influence each other. Plausibly, the translator should consider the cultural and linguistic differences when translating a cultural text into another listener or audience; that is because language and culture co-exist, and the former does not exist apart from the latter (Sapir 1970:2017).

Culture constitutes a very key element in the communication process. In linguistics, phraseology refers to fixe expressions such as idioms, proverbs, phrasal verbs and other types of multi-word lexical units whose component parts take on a meaning which might not be predictable from the sum of their meanings when used independently. Because of its cultural specificit, phraseology seems to be a discipline that well interprets and reflects the cultural framework of a whole society in the language as manifested in phraseological units like proverbial and idiomatic expressions. Therefore, it is also the field of study which seeks to provide an explanation of stable expressions containing words loaded with a cultural meaning. Such phraseological units play an important role in the language foundation and as such they need a special attention due to the fact that their meaning cannot be arrived at if they are not motivated, i.e., to trace back their history and etymology in addition to following the development stages of the meaning of their word constituents.

As far as the meaning of phraseological units is concerned, it ranges from being transparent to almost opaque. This is determined by the level of idiomaticity characterizing these culturally bound and fixed expressions which break the rules of semantic compositionality. Of course, communication is carried out through the use of language which is rooted in a cultural context and the way it is organized displays how its speakers perceive the world. In this vein, many thinkers have urged that large differences in language cause large differences in experience and thought. They claim that each language embodies a worldview, with quite different languages embodying quite different views, and thus speakers of different languages think about the world in quite different ways. Johnson (1981) claims that cultural inheritance may cause misunderstanding the intended message because of the cultural images related to the words or to the partial syntactical meaning of a context.

\section{THE TRANSLATABILITY OF PROVERBS}

Addressing the translatability of proverbs, maxims or aphorism is a linguistic endeavor that investigates equivalence above word level. This of course poses, due to a variety of factors the most important of which are the cultural ones, the challenge of non-equivalence in translating Arabic proverbs into English and vice versa. Since proverbs in Arabic can contain collocations, metaphors and idioms, they pose the most common lexical problems encountered in cross-cultural translation. As stated earlier, the wider the gap between the source and target culture, the more serious problems would be. Translation between Arabic and English which belong to two different cultures (the Oriental and the Western cultures), and which have a different background is a best example of such difficulties. Cultural problems may include geographical, religious, social and linguistic ones. For example, the expression 'summer's day' in Shakespeare's sonnet "Shall I compare thee to a summer's day" might be best translated into Arabic as 'spring's day' to convey the equivalent meaning.

The term culture refers to a set of beliefs that control a particular country or group behaviors. It is defined by Taylor (cited in Hymes, 1964:455) as a "complex whole which includes knowledge, beliefs, customs and any capacities and habits acquired by man as a member of a society". Among these beliefs, language is considered as an essential part that constitutes one's culture. This is involved in the process of translation through the influence of the source and target cultures. Culture has a great influence on the process of translation in the sense that the degree of integration of the source text (ST) in the target culture (TC) may vary, and may cause serious problems for the translator. In this respect, cultural diversity can yield different types of translation.

There can be many problems and difficulties encountered when translating. According to Yowelly and Lataiwish (2000:107), the bigger the cultural gap between the source language and the target one, the more serious these difficulties will be. The translations from Arabic into English or vice-versa help understand the differences better as the speaking countries of the two languages have different cultures, past and background. Cultural problems include geographical, religious, historical, linguistic etc. elements. To know a language, one should know the culture, traditions and customs of the speakers of that language. The cultural element can constitute an integral part of the total meaning of the word or word-combinations which is best manifested in idiomatic and proverbial expressions as they tend to rely heavily on images, traditions or habits, which are characteristic of a given culture.

Translation may, sometimes, result in a "shift towards the target culture, and the translated text may or may not merge completely in the target culture" as Yowelly and Lataiwish (2000:107) put it and which they called "integration". They further add that translation may preserve only the source 
culture (SC), and in this case it is termed "source translation". It may also preserve neither the source nor the target culture, and here, it is called "alienation" (ibid: 106).

Proverbs, like idioms, are not always transparent, and their meanings are sometimes ambiguous. However, language users highly favor them in their everyday use since they are always intrigued with expressive colorful language. They are also a part of figurative language that produces cul-tural information.

\section{DISCUSSION}

As mentioned in the above introductory part, translation of proverbs is not an easy task; it requires enough knowledge in both languages and cultures. The translator should be encyclopedic in the proverb, as it is not only the linguistic part which the translator should be aware of, but the extra-linguistic part, as well. Proverbs have etymological and situational histories that should not be ignored in translation. Besides, the social and cultural contexts should be considered in translation as situations change by time, though they may preserve the same themes. In other words, a source language comparison between similar events should be considerably taken into account in order to have full comprehension of the situation, and then translation should be made on the ground of that.

As Arabic proverbs are normally effective, connotative, stylistic, and forceful, mismatch in translation may result from the variation of the emotive power practiced on both texts' readership. As Leech (1981:16) puts it "affective meaning is largely a parasitic category in the sense that to express our emotion we rely upon the mediation of other categories of meaning-conceptual, connotative, or stylistic". In order to uncover the various problems of translating Jordanian proverbs into English, a number of proverbs is selected to represent these problems. As will be shown below, proverbs representing different themes are investigated to point out the various problems.

\section{Examples}

$$
\begin{aligned}
& \text { 1. سارحة ورّب ر اعيها sārhhih wir rab rā' '̄hā (lit. grazing and } \\
& \text { God (ord) is its shepherd) }
\end{aligned}
$$

The fact that people sometimes undergo certain times of stress, boredom, anxiety, and depression leads them to be inattentive and daydreaming. This state of carelessness, as many people may think, is derived from worries that people usually come across and experience. Expressing the situation and describing the state is denoted through a successful proverbial composition, by linguistically and culturally well-equipped people, and those of long life experience. The proverb under discussion shows that its constituents are strongly related to the environment, where people of similar experiences can understand all cultural and social connotations. Due to the long history of proverbs, they may acquire literal and idiomatic senses, and may be socially comprehended with all those senses. As Baker (2011:72) puts it "the proverb may be used in the source text in both its literal and idiomatic senses at the same time".
The Arabic colloquial proverb سارحة ورّب راعيها (lit. grazing and God is its shepherd) holds many social and cultural allusions. Reference to سارحة 'grazing' stems its significance from the pastoral culture of Arabs who have tight relations with pastures, and outdoor activities such as grazing animals and growing crops. In desert or open-ended regions, she-camels, sheep, and other cattle exert relentless efforts to satisfy their food needs. Therefore, nothing can interrupt them as food is their utmost need in regions that suffer from grass dearth. In other words, grass is the utmost need of such animals, and they try to obtain it by all means, while being careless about all other issues. The case being so, implications have extended to refer to those who are absent-minded, and sometimes careless people. The frequent use of the saying has been boosted with a proverbial sense that made it the talk of the town. In addition, though the proverb was firstly constructed to denote female animals, it has become suitable to connote people, regardless of their gender and has held many ironic allusions.

Translating the proverb into English collides with many cultural problems that can only be resolved by providing the translated version with commentary details that can bridge the cultural gaps. In other words, some proverbs may not have similar equivalents in the target language, as target language culture could not have experienced those same events; this leads to translation difficult (Baker 2011:71). Information such as reference to the she-camel which was firstly denoted by the proverb is vital to illuminate the cultural values and connotations that might not be conveyed in the target language. In addition, religious implications which constitute a large part of the total meaning of the proverb should also be explained in the target language. For example, spiritual values represented in the reliance on God for sustenance is clear in the source text, but cannot be relayed in the target language due to religious differences where people in the Western culture always refer sustenance to one's efforts and not to God's bestowment.

Semantically, the Arabic lexical item راعى is polysemous; i.e, it has a variety of meanings. The various meanings that the word entails, 'shepherd', 'care taker', 'patronage man' among many others may pose translation challenges as the translator should be successfully selective. The translator should contextualize the proverb in order to exempt unrelated meanings such as the one related to 'patronage' though a certain sense of meaning exists. S/he should enjoy enough linguistic and social culture of the proverb before attempting to render it into a different cultural environment. To retrieve it in Nida's (1954:14) words, “the most important step for the translator towards producing an accurate translation is to bear in mind respecting cultures, regardless of their spread". 2. قرد بعين امه غزال qird ib 'ayn ummuh ghazāl (lit. the monkselike gazelle in his mother's eye).

It is no doubt that intimacy between parents and sons start from the first moment a baby is delivered. This maternity makes it indispensable that sons are too dear to parents, regardless of how they look or behave. The fact that social relations are so clear and strong in traditional communities, like the Jordanian one, has made it vital that parents are usu- 
ally accompanied by sons. By nature, immature sons very often behave unconsciously and sometimes trouble others by their actions or wayward behaviors, a fact that keeps parents attentive and vigilant over them all the time.

Due to the companionship between sons and parents, the latter tend to connote the former with the best names and wish them all the luck. This has led to look at sons through the lens of beauty and well-mannered standards. In the Eastern culture in general, and the Islamic culture in particular, monkey is looked at as an ugly animal that nobody likes to be compared with. It should also be added that it is not only the way the monkey looks which is unfavor-able, but also the low position that the monkey has gained, a fact that the unbelievers are metaphorically described as this animal as shown in the Qur'an, Chapter Two, verse 65 (ولقد علمتم الذين اعتدوا منكم في السبت فقلنا لهم كونوا قردة خاسئين), which Ali (2003:34) translates as "And well ye knew those amongst you who transgressed in the matter of the Sabbath; We said to them: "Be ye apes, despised and rejected".

Rendering the proverb قرد بعين امه غز ال literally into En-glish as 'the monkey is like gazelle in his mother's eye' or functionally as 'beauty is in the eyes of the beholder' does not reflect many social and cultural allusions. The fact that the monkey is looked as merely an animal in the western culture deprives the source text proverb from the cultural dimensions entailed in the source text. Meanings of ugliness, despise, in-feriority, dirt, and rejection cannot be preserved similarly in the target language, where monkeys are given enough care and attention. Besides, senses of intimacy, mother-son rela-tions, and the high position that sons have in their parents' view cannot be relayed likewise in the translated version. Not only this, more focus is shown on mother's relation with sons in the source text; this might be stemmed from the fact that little sons normally remain with their mothers more than with their fathers. This might justify why the proverb in the source text has inclined to include the 'mother' and not the 'father'.

What may add to the translation problems is that gender, mother in the source text, is not considered, as the proverb can also be uttered when the son is in the company of the father, elder son, cousin, uncle, or aunt and so on. Readers of the translated text may think that the proverb can only be uttered when the sons or daughters are in company of mothers only, and not when they are in company of other rel-atives, for example. As observed, various meanings are en-tailed from the short proverb, and they are indirectly meant. This supports the idea that the proverb is supposed to be short, but users should interpret it at all levels to illuminate its social and cultural senses. To quote Trench (1953:16) "a proverb must have shortness; it must be succinct, utterable in breath.......compatible with full and forcible conveying of that which it intends". 3. ثلثين الولد لخاله thil thein 1 walad la khā luh (lit. two thirds of the boy are his uncle's)

It is worth indicating that social values in a certain community are culturally designed and the relationship between the customs of a society and the culture to which the individuals of that society belong is tight. In the Arab world in general, the paternal uncle is more involved in one's issues or debates; this, however, does not mean that the maternal uncle is not involved or cannot interfere in his nephew's affairs. What has given the former uncle the priority in the Arab community is the tribal system, which is based on one's descending fathers and not mothers, especially if the mother belongs to a different family or clan. This idea is clear from the following verses where paternal uncles and aunts are mentioned first, then followed by maternal uncles and aunts: "Prohibited to you (For marriage) are:- Your mothers, daughters, sisters; father's sisters, Mother's sisters; brother's daughters, sister's daughters; foster-mothers (Who gave you suck) (chapter 4:23); and "It is no fault in the blind nor in one born lame, nor in one afflicted with illness, nor in yourselves, that ye should eat in your own houses, or those of your fathers, or your mothers, or your brothers, or your sisters, or your father's brothers or your father's sisters, or your mother's brothers, or your mother's sisters, or in houses of which the keys are in your possession, or in the house of a sincere friend of yours: there is no blame on you, whether ye eat in company or separately" (chapter 24:61).

In order to comfort and compliment maternal uncles, the proverb ثلثين الولد لخاله, (literally, two thirds of the boy are his uncle's) is uttered, especially when there is a gathering of both parents' relatives. The message that the speaker most likely wants to convey is that one's maternal uncles are not exclud-ed from the blood relations, as more than half of the boy is for his maternal uncles. The boy's behavior is governed by his relations with those uncles, mainly when the behaviors are socially acceptable and approved. The proverb gains its un-changeable features and references from its inherited use; the maternal uncle is referred to in the proverb, and as such it has become self-coined saying at all linguistic and non-linguistic levels and cannot be replaced; none of the grammatical and syntactic constituents can be replaced as fixedness of proverb structure is elemental in its folkloric meanings.

Translating the proverb into English literally as "two thirds of a boy are his uncle's" does not show many social, cultural, and linguistic values due to the cultural distance between the Jordanian speakers of the source language and the western listeners of the target language. Social meanings such as the tight and intimate relationships between the Jor-danian family and clan system cannot be preserved in the target language. That is because family relations of the target culture are either weak or even nonexistent, not only at the maternal level but also at the paternal one. Culturally, mean-ings such as compulsory contribution in 'blood payment', in case of killing, and sometimes the compulsory leave of the killer's family from the place of residence for the same rea-son, for example, cannot be preserved in the target language. In order to compensate these translation losses, the translator should reinforce his translation with linguistic, social, and cultural details to ensure relaying enough meanings of the source language proverb.

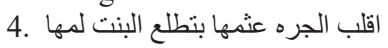

ig lib l jar rah 'a thum ha ib tid la' l bint lam ha (lit. turn the jar on its mouth, the daughter becomes like her mother)

Jordanian community can be described as masculine and in most cases men are in charge of authority and home running. The fact being so, daughters usually spend most of their time with their mothers, where they acquire behav- 
ior and manners. In other words, daughters are most likely imitators of their mothers' behavior and they tend to follow them in social interaction and deeds. As fathers are normally dominating, they resort their daughters' manners and behaviors to mothers, exempting themselves from any wrong that such daughters might make or commit.

Often but not always, daughters are looked at, not only by fathers, but also by the society as a whole, as a cloning of their mothers in behavior and sometimes in the way they look. In the Jordanian community, where men are heads of the family state, the colloquial proverb

اقلب الجره عثمها بتطلع البنت لمها (lit. turn the jar on its mouth, the daughter becomes like her mother) is uttered when daughters misbe-have or wrongly act or react. However, fathers may compli-ment daughters in the presence of mothers and praise them for doing a good deed by saying this proverb. Social and cul-tural background of the Jordanian community has led to the creation of this proverb, where turning the jar down empties it from water which is a necessity in Jordan due to shortage of water; the jar without water is nonsense and of no value, and the same applies for the daughter who is similar to her mother, as might be understood from the proverb's social use.

The literal translation of the verb 'turn the jar on its mouth, the daughter becomes like her mother' or even functionally as 'like a father like a son' has many translation challenges that cannot be overcome without supporting the translation with enough social and cultural details. In English, "like a father, like a son" can be a functional translation of the Ar-abic proverb, but the social and cultural implications of the source text cannot be relayed and thus understood similarly by target language readers. Besides, the English equivalent is in favor of the father or mother, which is not the case of the Jordanian proverb which reflects the unacceptable side of the mother. In addition, focus is laid on the mother in the source text, while this focus is on both parents in the tar-get text, though 'father' and not 'mother' is resorted to in the proverb. Moreover, the 'son' which indicates 'son and daughter' is used in the target language, while 'daughter' is in the source text. 5. it țal la' ala l an zeh wut lub ha lìb (lit. look at the goat and seek milk)

A pertinent relationship between man, environment and his source of living is virtually certain and eco-systematic. Arabs, who are connoted as people depending on agriculture and cattle as ways of life, have launched proverbs from their living experience in such habitats. The proverbs they produce depict their culture and address their lifestyle activities and experiences. Life implicitly characterizes people who rely on cattle and livestock for their life, as is the case of many Jordanians, whether in the countryside or in the Badia. The Jordanian proverb اطّلع على العنزة وطلب حليب (lit. look at the goat and seek milk) illustrates the relationship be-tween people and environment. The fact that goats (black sheep) are generally featured of not giving as much milk as sheep (white sheep), for example, has driven Jordanians to produce this proverb to describe other living situations. Socio-culturally speaking, the proverb has many implicit messages to be conveyed that cannot always be understood by all social groups, especially those who have experienced just a TV screen scene of the animal, and have taken the goat's milk as powdered or canned. The case being so, not all social communities can understand the implications of the proverb, an issue that might cause some misunderstanding. What contributes to the complications of misconception is that the addressee in the proverb is asked to look at a goat, supposedly present, and seek milk. Completely unaware of all the socio-cultural dimensions, fully ignorant persons of the Jordanian culture may look around and look for the goat or the milk. Practically, the proverb can be used in many social situations; for example, if a person is supposed to do a certain task and failed in doing it properly, someone expecting such performance may ironically say, describing the task performer "look at the goat and seek milk"; another situation where the proverb can be used is when a gentleman refuses to get married of a lady who is not beautiful, for example; he might express his refusal by saying "look at the goat (meaning the lady) and seek milk".

Translators of the proverb into English may be encoun-tered with many translation problems and challenges. At the sociocultural level, target language readers would not gain enough information from the literal translation of the proverb, due to the clear social and cultural distance between Arabic and English environments. In the very sense of the word, the proverb could have been created to describe a skinny, rawboned, emaciated, and thus non-milk giving goat, because of the lack of food and famine. In contrast, goats in the western culture can hardly be identical to those de-scribed in the proverb because of food abundance, pastures, and medical care, for example. Thus, the social values of the source text proverb cannot be grasped likewise by target language readers; in order to compensate this social and cul-tural loss, the translator should support the literal translation with supplementary details that can uncover all these layered meanings. In addition, the influence that the proverb may cause on the source text denoted person cannot be created on the audience of the target culture; the audience of the two cultures might have not have the same experience, and more importantly westerners are not as direct and are less harm-ful than Jordanians when uttering such a proverb to describe someone. 6. القر عا بتتباها بجدايل بنت خالتها il qar'a ib tit bāha ib jadā yel bint khā lit hā (lit. the short-haired lady boasts with the hair lock of her maternal female cousin)

It is axiomatic that proverbs benefit from cultural features and social values people. In the Jordanian culture, for example, long hair was until very recently a symbol or a sign of beauty for ladies. In marriage or even love market, this feature was a requirement that ladies should enjoy to gain some acceptance of the other gender or sex. This fact has driven young ladies to take care of their hair and keep it long to promote themselves for marriage.

The Jordanian proverb القرعا بتتباها بجدايل بنت خالتها (lit. the short-haired lady boasts with the hair lock of her maternal female cousin) has many cultural manifestations that reflect the Jordanian community, mainly till the beginning of the eightieth in the past century. The proverb reveals the social tight relationship between Jordanian families in general, and relatives in particular. It indicates that the hair lock of one's relative is his or hers, and one has the right to feel proud of relatives' good features. 
Another social issue that can ema-nate from the proverb is that females tend to be closer to their maternal cousins as mothers of maternal cousins normally meet together in the presence of their daughters. The fact be-ing so, proverb producers have successfully chosen its words to express feelings toward certain social situations. The col-loquial proverb can be uttered in certain social situations and circumstances; to illustrate, if somebody is unsuccessful or even failing in doing a job, s/he may say in such a situation that his/her relative is professional in that job but not him/ herself. Another example that may reflect the same point is when a lady is informed or denoted as not beautiful; she may say that her cousin or even sister is too pretty or beautiful. The response to such excuses by others is the utterance of the proverb القرعا بتتباها بجدايل بنت خالتها (lit. the short-haired lady boasts with the hair lock of her maternal female cousin).

As far as translation is concerned, the proverb poses tremendous translation problems at many levels, socially, culturally, psychologically, linguistically, and emotively. In the western culture, for example, where the proverb may be translated, there are no family tight relations that can show intimacy between female cousins; they may even not know each other at all. In addition, long hair might not be a sign of beauty among the westerners who could prefer some haircut styles. More significantl , the simplicity of the proverb itself which is exclusive to the Arab environment cannot be creat-ed likewise in the target language. All this necessitates that the translator support the translated version with explanatory details to uncover the unseen values, hidden behind the so-cial and the cultural cloak.

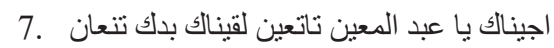

ajīnāk yā abd l mu'īn tāt 'ìn la gai nāk bad dak tin 'ān (lit. Oh Abd Mu'in, we have come to you for help, but found you in need of help)

The Arab community such as the Jordanian one is fea-tured as helpful. Traditionally, this feature extends from the very simple need that a neighbor may need such as a piece of bread to the utmost one, depending on the type of relation that links between people. When the targeted person apol-ogizes to offer help for one reason or another, he or she is

الجيناك يا عبد المعين تاتعين لقيناك بدك تنعان addressed by the proverb "lit. Oh Abd Mu'īn, we have come to you for help, but found you in need of help".

The Jordanian colloquial proverb is socio-culturally loaded with meanings that can be understood by a large sector of the community. Besides, the proverb has religious connotations as one of Allah's names, namely 'mu'īn', 'helper' is associated with the proverb. The intentionally added name is related to the occasion of uttering the proverb which is asking for help, regardless of the type of help. It might be physical or spiritual. Utterance of the proverb can be possible if someone asks another to carry a heavy item, for example, and the latter could not because of physical power. The latter can be denoted by the proverb illustrating that he himself needs help, how come that others need him to offer help. Experiencing similar psychological problems can also be another case in point; to illustrate, people suffering from psychological problems can seek remedy of the problems from those in charge, and in case those in charge could not offer any help, the proverb is uttered.

Translating this proverb poses many translation problems at all levels, socially, culturally, religiously, and psycholog-ically, so to speak. The fact that there is no intimacy among people in the western culture, who are basically materialis-tic by nature, does not give the chance for someone to ask for money help, for example. This cultural value which is relatively a phenomenon in the Jordanian culture cannot be conveyed when the proverb is translated as "lit. Oh Abd Mu'in, we have come to you for help, but found you in need of help". Though Abd Mu'in is a proper name, it does not refer to someone called by this name, but for the sake of the proverb rhythm 'Abd Mu'in and tat'in' are used which again cannot be preserved in translation as 'Adb Mu' in and help'. The name Abd Mu'in is masculine but can be used in situations of both genders, males and females, which is another translation loss when translating the proverb literally in the target language. More importantly, the proverb has religious connotation when 'Mu'in', one of Allah's names is associat-ed with 'abd', meaning 'slave'.

\section{8. رجعت حليمه لعادتها القديمة}

rij'at halìma la 'ádit ha l gadìma (Halima has returned to her old habit).

By nature, it is difficult for someone to quit what he is used to doing, especially if he has been so for a long time. Intentionally or unintentionally, a person may act or behave in a certain way without feeling that this behavior is socially or communally unacceptable or disapproved.

Arabs, by nature, are featured as hospitable, and generous despite the severe conditions that they may undergo. They offer all they have for their guests, especially food when they are hosted. The fact that Hatim Al-Ta'ei slaughtered his female horse, the only horse he had for his guest, has made him an example of generosity throughout the Arab history. His wife was however too stingy, and this irritated him a lot. He decided to change her behavior by fabricating a story that one's hair never becomes grey if one adds to much ghee in food. This has made her change her mind for a short time, but hair her turned grey and not as she was told. Therefore, she decided to behave as she used to in her past, by adding too small amount of ghee on the food. The guests noticed that and they uttered "Halima has returned to her old habit".

The utterance has gained enough reputation over time, and has extended to apply on different events, occasions, and situations. The inclusion of new uses has also extended to include males although the proverb was firstly uttered to describe a female. To illustrate, if a child stops behaving wrongly after being advised by parents, that would be highly appreciated; however, if that child turns to his bad habit, he will be denoted by the proverb "Halima has returned to her old habit". Translating the proverb into English literally would strip it from many social, cultural, and historical values and implications. Historical meanings such as the generosity of Arabs cannot be relayed and preserved in the target language where people are pragmatic and every penny counts. Not only this, the fact that the proverb extends 
to denote males may not be easily noticed in translation as readers may think that such a proverb is exclusively used to connote women. Besides, the situations where the proverb applies cannot be fi ured out by target language readers due to cultural differences.

\section{CONCLUSION}

On the basis of the inspection of the issue under discussion, this study has come to fi ure out that translation of proverbs is not an easy task due to their various idiosyncrasies. What may complicate the issue of translating Jordanian proverbs into English is the cultural load, which cannot be easily resolved in translation. Colloquialism adds to the difficulty of translation as proverbs are folkloric and are used frequently between common people. Translators, thus, should be considerate of all the values of such proverbs when rendering them into a different culture, like that of English. They should also uncover their real story and etymology as this clarifies them better and makes their applications clearer. Another important point that should be considered in the translation of proverbs is their function; i.e., they are used in similar situations and can convey the same social meaning. The study has shown that Jordanian proverbs are culture-bound; they are linguistically and culturally complicated, and therefore translationally fallacy-ridden, due to a number of linguistic and extra-linguistic variables that were investigated throughout the paper.

\section{REFERENCES}

Armstrong, N. (2005). Translation, Linguistics, Culture: A French-English Hand Book, Great Britan: Cromwell Press Ltd.

Baker, M. (1992). In Other Words: A Course Book on Translation. London: Routledge.

Ball, W. J. (1968). A Practical Guide to Colloquial Idiom. London: Longman Group Ltd.

al-Budayri, A. (2015). Linguistic and Cultural Difficulties in the Translation of Proverbs Used in Najd, Unpublished MA Thesis, Al-Imam University, Riyadh: Saudi Arabia.

Burger,H., Dobrovol'skij, D., Kühn, P., Norrick, N. (eds.). (2007). Phraseology. An International Handbook of Contemporary Research, Berlin, NewYork: Walterde Gruyter.

Carter, R. (1993). Introducing Applied Linguistics, London: Penguin Books.

Catford, J.C. (1980). A Linguistic Theory of Translation. An Essay in Applied Linguistics.

Fernando, C. (1996). Idioms and Idiomacity. London: Penguin Books.

Ghazala, H. (1995). Translation as Problems and Solutions, $4^{\text {th }}$ editon, Syria: Dar El-Kalem El-Arabi.

Grzybek, P. (1994). "Proverb", in Simple Forms: An Encyclopaedia of Simple Text Types in Lore and Literature, ed. Walter Koch, Bochum: Brockmeyer (227-241).

Hartch, E, \& Brown, C (1995). Vocabulary, Semantics and Language Education. Cambridge: Cambridge University Press.

Hitti, P (1985). History of the Arabs. New York: Macmillan. Hymes, D (1964). Language in Culture and Society, New York: Harper and Row.

Johnson, P (1981). Effects on Reading Comprehension of Language Complexity and Cultural Background of a Text. TESOL Quarterly, 15, 2, pp 169 - 81.

Kharma, N. (1997). Translation, $1^{\text {st }}$ edition, Al Quds: Al Quds Open University.

King, G. (2000). Good Grammar. Glasgow: Harper Collins Bublishers.

Kirkpatrick, M. (2004). Every Day Idioms. Singapore: Learners Publishing Ltd.

Leech, G. (1981). Semantics: The Study of Meaning, $2^{\text {nd }}$ edition, Penguin: Harmondworth.

Meider, W. (1985). Proverbs: A Handbook, $1^{\text {st }}$ ed. Greenwood Press: London.

Mieder, W. (2003). Proverbs and Their Lessons, Burlington, Vermont.

Mieder, W. (2004). Proverbs: A Handbook, Westport, London: Greenwood Press.

Mieder, W. (2007). "Yankee Wisdom: American Proverbs and the Worldview of New England," in Skandera (205234).

Muntean, G. (1969). Cercetări literare, Bucureşti: Editura pentru literatură.

Nida, E. (1954). Customs and Cultures: Anthropology for Christian Mission, Harper and Row: New York.

Norrick, N, R. (1985). How Proverbs Mean? Semantic Studies in English Proverbs, Mouton: Amesterdam.

Piirainen, E. (2007). "Phrasemes from a Cultural Semiotic Perspective," in Burger, H. et al. (pp.208-219).

Sabban, A. (2007). "Culture-boundness and Problems of Cross-cultural Phraseology,” in Burger, H. etal. (590604).

Sapir, E. (1970) Language, Harcourt Brace, New York.

Skandera, P. (ed.) (2007). Phraseology and Culture in English, Berlin, New York: Mouton de Gruyter.

Taylor, A. (1994). "The Wisdom of Many and the Wit of One," in Mieder; Dundes (pp. 3-9).

Trench, C. (1953). On the Lessons in Proverbs, Redfield: New York.

Yowelly, A., \& Lataiwish, M.S. (2000). Principles of Translation, Dar Annahd Alarabiya: Libya. 